\title{
Segmental Pronunciation Errors Made by the Lamaholot Speakers of Junior High School Students
}

\author{
Yoanes Octovianus L. Awololon ${ }^{1}$, I Wayan Pastika ${ }^{2}$, Anak Agung Putu Putra ${ }^{3}$ \\ Octhoviandryawololon@gmail.com \\ Udayana University, Denpasar 80114, Indonesia
}

\begin{abstract}
This study is entitled Segmental Pronunciation Errors made by the Lamaholot Speakers of Junior High School Students. It aims at revealing how the pronunciation errors were made and investigating the factors that caused the errors. The data of this study were obtained from the Simak Libat Cakap by the use of bait questions conducted on 10 second-graders of a Junior High School in East Adonara district, East Nusa Tenggara Province, Indonesia. The Simak Libat Cakap Method with the bait question was used to get how the students pronounced the basic English words. The observation method was used to observed the student's articulators. The documentation was used to gain some previous studies related to the phonological contrastive analysis between the Lamaholot language and English. The data of the study were qualitatively analyzed based on three branches of phonetic theory by Crystal (2008) and the factors causing errors by Brown (2000). The analysis of this study was presented in formal and informal method, each problem in this study was descriptively presented. The finding revealed that the students tended to make errors in pronouncing the consonants rather than any vowels. Those consonants pronunciation errors were

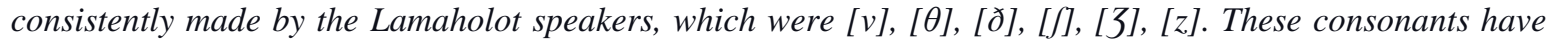
not existed in the phonetic chart of Lamaholot language. Moreover, the speakers also consistently did not pronounce the $[p]$ and $[d]$ in the case of consonant clusters distributed in word-final distribution, which are not recognized in the Lamaholot syllable structure.
\end{abstract}

Published by IJRP.ORG. Selection and/or peer-review under responsibility of International Journal of Research Publications (IJRP.ORG)

Keywords: Segmental, Pronunciation, Errors, Lamaholot Language

\section{Introduction}

With the enormous development and vast globalization, English is required to be major as it has spread and dominated in every sector as in economic, industry, health, education, and entertainment. As time goes by, with the development of science and technology, people compete to learn English. Meanwhile, it has been arguable that learning English as a target language is difficult, more than learning the first language or learning a mother tongue. It is caused by different aspects and language systems, such as; pronunciation, spelling, and cultural background. The goal of learning a target language is to ensure that the learners can communicate what they have in mind effectively and have to be understood when they are uttering the words. Having a good pronunciation of a language is essential for effective communication, particularly intelligibility because incorrect pronunciation can also hinder knowledge construction. 
Odden (2006: 2) relates pronunciation to the foundation areas of linguistics that deal with the scientific study of the language structure, that is, phonology. Moreover, the phonological level is a field of linguistics that is completely dependent on text data with phonetic transcription. Phonetics is a linguistics field that targets the sound of language pronounced in a speech to be described, classified, and transcribed (Pastika, 2019: 9).

As the phenomenon found related to the sound of language pronounced, the Lamaholot speakers often made some errors in pronouncing a single sound in a word. For example, the learner does not articulate the sound [g] and replaces [j] to [s] in the word English. Learners often pronounced [Inglif] with [inlis]. In the word mouth, the learners mostly pronounced [mav $\theta$ ] with [maut]. Therefore, the English language in the area of pronunciation is found difficult to master because there are several English spelling may be represented by a single sound (Vernick and Nesgoda, 1980: xi). In line with that, Lanteigne (2006: 1) also reveals that difficulties in learning English occur since some English sounds do not exist in the learners' mother tongue. As the example that can be seen in the Indonesian language; English sounds such as [v], [ $\theta],[\delta],[3],[\mathrm{d}]]$, and [t $\left.\int\right]$, cannot be found either. Furthermore, the way of pronouncing one particular sound may be different based on word distribution. As an illustration, [g] in good [god] and in large [la:rd3] is differently pronounced.

Besides, the research on the English pronunciation errors made by the Lamaholot speakers in East Adonara has not been conducted much. Thus, the study by taking an applied linguistic point of view needs to be conducted for developing students' pronunciation skills based on their learning difficulties as a needs analysis. In this case, the results obtained are more detailed to be applied as a reference to design an effective lesson plan in language teaching. Furthermore, choosing the second-graders of Junior High School because they have had the basic knowledge of how to pronounce English segmental sounds. In contrast, it was hard for those students to practice their pronunciation, which made them shy to try speaking English. Knowing that the students had great motivation to speak English fluently, finding their segmental pronunciation errors as learning difficulties was of paramount importance and crucial as need analysis. Hence, this study aimed to describe phonetically how the Lamaholot speakers made the pronunciation errors and reveal the possible factors that caused these English segmental pronunciation errors.

\section{Theoretical Framework}

\subsection{Phonetic}

Chaer (2009: 10), in his book entitled "Phonology of the Indonesian Language" stated that phonetics is the sound system of a language. On the other hand, phonetics is the systematic study of speech sounds, which is physical and directly observable (Odgen, 2009: 1). To sum up, Crystal (2008: 363) defines phonetics as the science which studies the characteristics of human sound-making, especially those sounds used in speech, and provides methods for their description, classification, and transcription. Crystal then continued that three phonetic branches are generally recognized as (a) articulatory, (b) acoustic, (c) auditory phonetics.

\section{A. Articulatory Phonetic}

Articulatory phonetics is a phonetics branch that investigates sounds based on their speech tools/articulators (Ladefoged, 1992). Pastika (2019: 9) adds that some of the articulators are active and some are just as a support. The lips, tongue, and vocal cords are speech articulators that are actively moving, while the speech tools such as teeth, gums, palate, and phlegm are just as a support. Meanwhile, the essential part of the speech articulators is the resonator, which functioned to reflect or shift the air when the sound of language is processed. Systematically, the pronunciation of the consonant is based on the place and manner of 
articulation. There are some of the technical terms that are used for the different articulation places and manners according to Pastika (2019: 14-16) which is then formulated into the form of tables.

Table 1. The Places of Articulation

\begin{tabular}{ll}
\hline Place & Description \\
\hline Bilabial & The two lips coming together \\
Labiodentals & The lower lip touching the upper teeth \\
Dental & The tip of tongue near the upper front teeth \\
Alveolar & The tip or blade of tongue touching or near the alveolar ridge \\
Post alveolar & The blade of tongue near the forward part of hard palate just behind the alveolar ridge \\
Palatal & The front of tongue near the hard palate \\
Velar & The back of tongue touching the soft palate (the velum) \\
Labiovelar & The lips approach one another, and the back of tongue raised towards the soft palate. \\
\hline
\end{tabular}

Table 2. The Manners of Articulation

\begin{tabular}{ll}
\hline Manners & Description \\
\hline Stop & Complete closure of vocal tract. Air is blocked from going out. \\
Nasal & Closure of vocal tract such that air can go out through nose, but not through the mouth. \\
Fricative & Constriction of the vocal tract so that a noisy airstream is formed. \\
Affricate & A stop followed by a fricative made at the same place of articulation. \\
Approximant & Construction of vocal tract to a smaller extent than that required for a noisy airstream. \\
Lateral & The tongue touching the roof of the mouth but without contacting the teeth at the sides. \\
\hline
\end{tabular}

B. Acoustic Phonetic

Acoustic phonetics is a branch of phonetics that studies the physical aspects produced by speech instruments are used as references to support articulatory or auditory phonetic analysis. However, do not hang language sound analysis complemented by acoustic analysis because electronic devices certainly have various limitations. The physics facts of language sounds are calculated using physics and mathematical concepts to determine the frequency of sound waves, amplitude, intensity, and duration (Pastika, 2019: 30).

\section{Auditory Phonetic}

Auditory phonetics, which is also the second supporting phonetic theory in this study, is a phonetic branch that studies the human ability to perceive language sounds. Furthermore, this auditory phonetic examines the relationship between the sound that is uttered as a stimulus. The response is normally given from the listener towards the sound (Muslich, 2008).

\subsection{Phonological Contrastive Analysis between the Lamaholot language and English}

According to Yarmohammadi (1995:19), contrastive phonology is the process of comparing and contrasting the phonological systems of languages to formulate their similarities and differences. Examination of the differences between the first and second languages helps to predict the possible errors that can be made by L2 learners. Since this study focuses on English as the language being learned by the Lamaholot speakers, it is then necessary to briefly discuss the contrastive analysis between the Lamaholot language (L1) and English (L2). 
A. The Lamaholot Language

Table 3. The Lamaholot Consonant

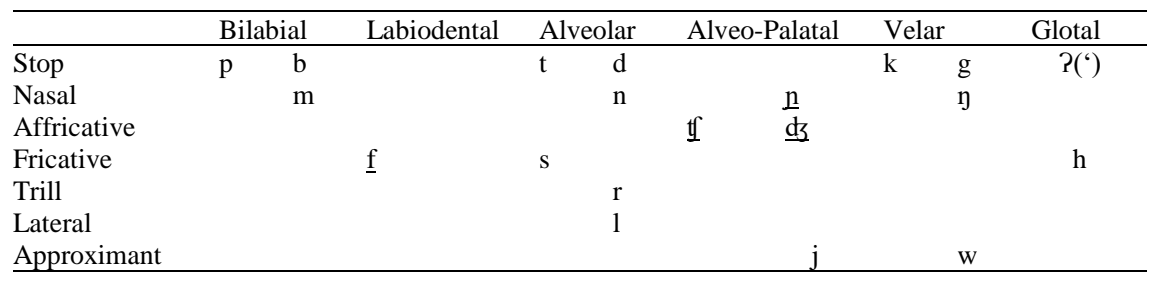

Table 3. shown that the Lamaholot language spoken in East Adonara has sixteen indigenous and four loan consonants phonetic (underlined). Those loan consonants are only found in borrowings from Indonesian and neighboring languages. Besides, the vowels in the Lamaholot language are divided into six nasal vowels and 6 oral vowels /i, e, ə, a, u, o/ and the their nasal vowels.

\section{B. English Language}

In General American English is generally described as having short vowels and long vowels. There are said to be six short vowels [I, $\varepsilon, æ, \Lambda, \mho$, ə], five long vowels [i:, a:, っ:, u:, 3 :].

Table 4. The English Consonant

\begin{tabular}{|c|c|c|c|c|c|c|c|c|c|c|c|c|}
\hline \multirow[b]{2}{*}{ Stop } & \multicolumn{2}{|c|}{ Bilabial } & \multicolumn{2}{|c|}{ Labiodental } & \multicolumn{2}{|c|}{ Dental } & \multicolumn{2}{|c|}{ Alveolar } & Post-alveolar & \multirow[t]{2}{*}{ Palatal } & \multicolumn{2}{|c|}{ Velar } \\
\hline & $\mathrm{p}$ & $\mathrm{b}$ & & & & & $\mathrm{t}$ & $\mathrm{d}$ & & & $\mathrm{k}$ & $\mathrm{g}$ \\
\hline Nasal & & $\mathrm{m}$ & & & & & & $\mathrm{n}$ & & & & y \\
\hline Affricative & & & & & & & & & ds & & & \\
\hline Fricative & & & $\mathrm{f}$ & $\mathrm{v}$ & $\theta$ & ð & s & z & 3 & & & \\
\hline Lateral & & & & & & & & 1 & & & & \\
\hline Approximant & & & & & & & & $\mathrm{I}$ & & $\mathrm{j}(\mathrm{y})$ & & w \\
\hline
\end{tabular}

Based on the discussion of the two languages above, there are some similar and distinctive features between the Lamaholot language and English. In spite of the similarities, there are four English phonemes that are not recognized in the Lamaholot language sound systems, i.e. [J], [3], [0], and [ð]. English short vowels [æ] and all English long vowels such as [i:], [a:], [॰:], [u:], and [3:] are not recognized in the Lamaholot language. From the discussion, it is clearly said that the similarities between the two languages will not cause any difficulties. Nevertheless, the different characteristics between them will definitely bring intricacy and problems in pronunciation during the learning process of the target language

\subsection{Cause of Errors}

The good reasons for focusing on Errors are; first, they are a clear feature of learner language. The next, it is useful for teachers to know what errors learners make. Ellis (1997: 15) suggests two ways in distinguishing between the errors and mistakes that the first one is to check the consistency of the learners' performance. If the learners sometimes use the correct form and sometimes the wrong one, it is a mistake. However, they always use it incorrectly, it is then an error. The second way is to ask the learners to try the correct their own deviant utterance. Where, they are unable to, the deviations are errors. Therefore, an error means a performance that is not correct because of some reasons, and the learners does not realize their incorrect 
action. Related to the errors caused by students, Brown (2000) defines one of the causes of errors is an interlingual transfer. The Interlingual factor refers to the interference factor from the learner's mother tongue or first language. This error occurs because of differences in the mother tongue system and the language system being studied. Thus the other caused of errors made by the students may caused by the inconsistency of the English sounds system as it stated by Hewings (2004).

\section{Methods}

The research design was a descriptive qualitative research. in conducting this research, the researcher focused on finding and describing phonetically the pronunciation errors of English segmental acquired and the factors caused the errors. Data collection used to gather and collect data. In this step, gathering and collecting data were Simak Libat Cakap and observation. Those techniques used to get the data to answer the research problems.

\section{Result and discussion}

\subsection{The Students' Mispronunciation of Consonants and Vowels}

The segmental mispronunciations found made by the Lamaholot speakers in pronouncing the words in the passage given. The researcher analyzed the segmental mispronunciation by the use of three branches of the phonetic subject according to Crystal (2008), they are articulatory phonetic, auditory phonetic, and acousticphonetic. Meanwhile, the researcher also applied two ways in distinguishing the errors and mistakes according to Ellis (1997) that the first, checking the consistency of the students' pronunciation. If they sometimes used the correct form and sometimes the wrong one, it was then a mistake. The second way was asking the learners to try to correct their deviant utterance. Where they were unable to, the deviations were errors. Hence, the researcher found some mispronunciation made by the Lamaholot speakers as detailed presented in the following discussion.

\section{A. The Voiced Labiodental Fricative [v] Consonant}

The students made errors in pronouncing this consonant distributed in all three-word positions in words television, video, and love.

\begin{tabular}{|c|c|c|c|c|c|c|c|c|c|}
\hline $\begin{array}{l}\text { /fidio/ } \\
\text { /tclefisən/ } \\
\text { /laf/ }\end{array}$ & $\begin{array}{l}\text { /fidio/ } \\
\text { /telefesen/ } \\
\text { /laf/ }\end{array}$ & $\begin{array}{l}\text { /fidio/ } \\
\text { /telefisən/ } \\
\text { /1 } \mathbf{f} /\end{array}$ & $\begin{array}{l}\text { /fidio/ } \\
\text { /tzlefesion/ } \\
\text { /laf/ }\end{array}$ & $\begin{array}{l}/ f \text { fdio/ } \\
\text { /telefesən/ } \\
\text { /laf/ }\end{array}$ & $\begin{array}{l}\text { /fidio/ } \\
\text { /telefison/ } \\
\text { /laf/ }\end{array}$ & $\begin{array}{l}\text { /fIdio/ } \\
\text { /tælæfisən/ } \\
\text { /laf/ }\end{array}$ & $\begin{array}{l}\text { /fidio/ } \\
/ \text { telefes } \supset \text { n/ } \\
/ \mathbf{l}_{\Lambda \mathbf{f}} /\end{array}$ & $\begin{array}{l}\text { /fidio/ } \\
\text { /tclefisən/ } \\
\text { /laf/ }\end{array}$ & $\begin{array}{l}/ \text { fidio/ } \\
\text { /tclefeson/ } \\
/ \mathrm{l} \mathbf{\Lambda} \mathbf{f} /\end{array}$ \\
\hline
\end{tabular}

Based on the articulatory analysis, the students were likely pronouncing the labiodental fricative by touching their lower lip against the upper teeth to form a noisy airstream. In contrast, the data revealed based on the acoustic analysis as the supporting evidence that there was no turbulence which spread in the lower frequency appeared in the voicing bar of wave spectrogram graph to indicate the voiced [v]. It means the students were articulating the voiceless labiodental fricative [f] consonant. Related to the voiced fricative, there was none of students who could pronounce the voiced [v] distributed in all word- position in the words television, video and love (see appendix figure 1). 


\section{B. Voiceless Dental Fricative [ $[\theta]$ and voiced [ð] Consonants}

The errors made by the students in pronouncing the consonant voiceless [ $\theta$ ] were distributed in initial and final word positions in words thanks and mouth. The voiced [ð] consonant is distributed in initial and middle word positions in words this and mother.

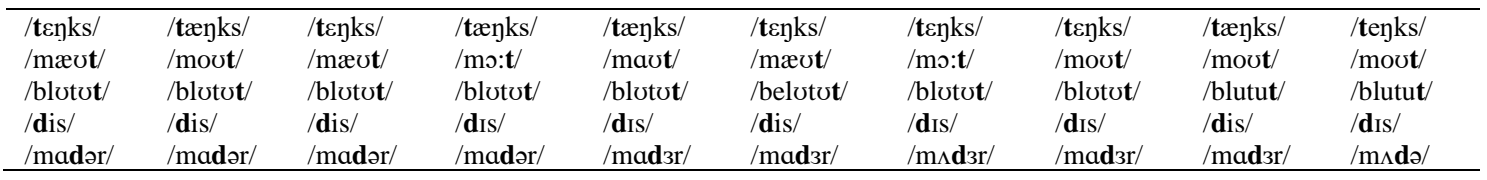

Based on the articulatory analysis, some students placed a very tongue tip come through the teeth to produce the voiceless [ $\theta$ ] and some of them placed it behind the bottom teeth to articulate the [ð] sound. In contrast, the pronunciation was not audible as they were pronouncing these fricatives both voiced and voiceless. The audio-recorded result showed that they replaced the voiceless [ $\theta$ ] to the voiceless alveolar [t] consonant and voiced [ð] to the voiced alveolar [d] consonant. Besides, based on the acoustic analysis shown in the appendix (picture 2 and 3) that dental [ð] has a lower second formant (F2) than alveolar [d] at consonant release in the vocal tract. The difference in F2 is due to a lower, more backed tongue body and a slightly longer back cavity for the dental than for the alveolar. This third data analysis had also revealed that the students replaced the dental sound with the alveolar for both voiced and voiceless (see appendix figure 2 and 3).

\section{The Voiceless Post-alveolar Fricative [S] and Voiced [3] Consonants}

The error made by the students in pronouncing the consonant voiceless [ $]$ ] distributed in initial, middle, and final word positions in words short, mission, and fish.

\begin{tabular}{|c|c|c|c|c|c|c|c|c|c|}
\hline $\begin{array}{l}\text { /sar/ } \\
\text { /misən/ } \\
\text { /fis/ } \\
\text { /Inglis/ } \\
\text { /tclefisən/ }\end{array}$ & $\begin{array}{l}\text { /sər/ } \\
\text { /misən/ } \\
\text { /fis/ } \\
\text { /inles/ } \\
\text { /telefesen/ }\end{array}$ & $\begin{array}{l}\text { /so:r/ } \\
\text { /missn/ } \\
\text { /fis/ } \\
\text { /Inglis/ } \\
\text { /telefisən/ }\end{array}$ & $\begin{array}{l}\text { /sor/ } \\
\text { /misæn/ } \\
\text { /fis/ } \\
\text { /Inglis/ } \\
\text { /telefesion/ }\end{array}$ & $\begin{array}{l}\text { /sar/ } \\
\text { /mesən/ } \\
\text { /fis/ } \\
\text { /Inlis/ } \\
\text { /telefesən/ }\end{array}$ & $\begin{array}{l}\text { /sort/ } \\
\text { /misən/ } \\
\text { /fis/ } \\
\text { /inlis/ } \\
\text { /telefisən/ }\end{array}$ & $\begin{array}{l}\text { /sart/ } \\
\text { /misən/ } \\
\text { /fis/ } \\
\text { /Enlis/ } \\
\text { /tælæfisən/ }\end{array}$ & $\begin{array}{l}\text { /sort/ } \\
\text { /misən/ } \\
\text { /fis/ } \\
\text { /\&ylis/ } \\
\text { /tclefeson/ }\end{array}$ & $\begin{array}{l}\text { /sart/ } \\
\text { /misən/ } \\
\text { /fis/ } \\
\text { /inglis/ } \\
\text { /tclefisən/ }\end{array}$ & $\begin{array}{l}\text { /sər/ } \\
\text { /misən/ } \\
\text { /fis/ } \\
\text { /inglis/ } \\
\text { /tclefesən/ }\end{array}$ \\
\hline
\end{tabular}

The voiced [3] consonant distributed in word-middle positions television. Based on the articulatory analysis, placed the lips and teeth just closed to normal, which looked like they were articulating these both voiceless [S] and voiced [3]. Although the tongue movement cannot be observed directly from the outside when students pronounced these consonants, the audio recording revealed that the students replaced the voiceless [J] with the voiceless alveolar fricative consonant [s] in the word fish final distribution. The students were also replaced the voiced fricative [3] with the voiceless [s] as it can be acoustically analyzed in figure 11 (see appendix). In the same vein, the acoustic data analysis presented the wave spectrogram that there was a high energy noise above $4000 \mathrm{~Hz}$ which indicated the characteristic of the voiceless [s] consonant. Moreover, the voicing bar shown in the second picture indicated that the energy noise was also around $4000 \mathrm{~Hz}$ indicated the [s] consonant because the characteristic of voice energy of voiceless [ $\mathrm{s}$ ] must be more than $2000 \mathrm{~Hz}$ or lower than [s] sound. Besides, there was no voicing energy in the lower frequency of F1 for indicating the characteristic of voiced [3] consonant. 
D. Voiced Fricative [z] Replaced to Voiceless [s]

As well as the other consonants above, this voiced alveolar fricative [z]was replaced to the nearest environment consonant voiceless alveolar fricative [s] that existed in Lamaholot language. Although, this [z] sound appeared in Indonesian but it does not in any words found in Lamaholot language spoken. This [z] consonant distributed in the middle and final word positions in music and close.

\begin{tabular}{|c|c|c|c|c|c|c|c|c|c|}
\hline $\begin{array}{l}{[\mathrm{klos}]} \\
{[\mathrm{m} U \mathrm{sik}]}\end{array}$ & $\begin{array}{l}{[\mathrm{kl} \text { lous] }} \\
\text { [mjusik] }\end{array}$ & $\begin{array}{l}\text { [kləs] } \\
\text { [musik] }\end{array}$ & $\begin{array}{l}\text { [klous] } \\
\text { [musik] }\end{array}$ & $\begin{array}{l}{[\mathrm{klos}]} \\
\text { [muIsIk] }\end{array}$ & $\begin{array}{l}\text { [kəlous] } \\
\text { [mjusık] }\end{array}$ & $\begin{array}{l}{[\mathrm{kl} \text { los }]} \\
{[\mathrm{mj} \text { josık] }}\end{array}$ & $\begin{array}{l}\text { [klous] } \\
\text { [musık] }\end{array}$ & $\begin{array}{l}{[\mathrm{klos}]} \\
{[\mathrm{mUsIk}]}\end{array}$ & $\begin{array}{l}\text { [klous] } \\
\text { [musik] }\end{array}$ \\
\hline
\end{tabular}

Based on the data transcription from students' pronunciation presented in the table above, the students replaced the voiced alveolar fricative consonants $[\mathrm{z}]$ to the voiceless [s]. The picture based on the acoustic analysis showed the variation of pronunciation that there is no voice bar in the spectrum object to indicate the voiced consonant in the final distribution above. The data found that the students replaced the voiced fricative with the voiceless sound distributed in the middle and final word position.

\section{E. The Voiceless Bilabial Stop [p] and Voiced Alveolar [d] Consonants}

Based on the place of articulation, both consonants stop above were different to pronounce. As the data found based on the articulatory phonetic, the students have likely pronounced the voiceless bilabial stop that the students moved their upper and lower lips simultaneously caused the air completely blocked from going out. In the same vein, for the voiced alveolar [d], the students were viewed placing their tongue to touch or near the alveolar ridge. As the phenomenon data found from the audio recording, both voiceless bilabial [p] and voiced alveolar [d] distributed in the word-final position in lamp and frien $\underline{d}$ were not audible.

\begin{tabular}{|c|c|c|c|c|c|c|c|c|c|}
\hline $\begin{array}{l}\text { /fran/ } \\
\text { /læm/ }\end{array}$ & $\begin{array}{l}\text { /fræns/ } \\
\text { /læm/ }\end{array}$ & $\begin{array}{l}\text { /fræn/ } \\
\text { /læm/ }\end{array}$ & $\begin{array}{l}\text { /fræn/ } \\
\text { /læm/ }\end{array}$ & $\begin{array}{l}\text { /fran/ } \\
\text { /læm/ }\end{array}$ & $\begin{array}{l}/ \text { fren/ } \\
/ 1 \varepsilon m /\end{array}$ & $\begin{array}{l}\text { /fran/ } \\
\text { /læm/ }\end{array}$ & $\begin{array}{l}\text { /fræn/ } \\
/ \mathrm{lsm} /\end{array}$ & $\begin{array}{l}\text { /fren/ } \\
/ \mathrm{lcm} /\end{array}$ & $\begin{array}{l}\text { /frin/ } \\
\text { /lem/ }\end{array}$ \\
\hline
\end{tabular}

This had also proven from the acoustic analysis outcome (figure $6 \& 7$ ) that there was only a silent line without any spectrogram pattern after the nasal sound for both consonants and no spectrum sign in the voice bar indicated the consonants vibration. This means that the students did not articulate these both stop sounds voiceless bilabial and voiced alveolar.

\section{F. The voiced Velar Stop [g] Consonant}

The errors made by the students in pronouncing the consonant voiced [g] distributed in word-middle positions in words English.

\begin{tabular}{|c|c|c|c|c|c|c|c|c|c|}
\hline $\begin{array}{l}\text { /gad/ } \\
\text { /gud/ } \\
\text { /Inglis/ }\end{array}$ & $\begin{array}{l}\text { /gad/ } \\
/ \mathbf{g u d} / \\
\text { /Inles/ }\end{array}$ & $\begin{array}{l}\text { /gad/ } \\
\text { /gud/ } \\
\text { /Inglis/ }\end{array}$ & $\begin{array}{l}\text { /gad/ } \\
\text { /gud/ } \\
\text { /Inglis/ }\end{array}$ & $\begin{array}{l}\text { /gad/ } \\
/ \text { god/ } \\
\text { /Inlis/ }\end{array}$ & $\begin{array}{l}\text { /gad/ } \\
\text { /gud/ } \\
\text { /inlis/ }\end{array}$ & $\begin{array}{l}\text { /gad/ } \\
\text { /gud/ } \\
\text { /eglis/ }\end{array}$ & $\begin{array}{l}\text { /god/ } \\
\text { /god/ } \\
\text { /eglis/ }\end{array}$ & $\begin{array}{l}\text { /gad/ } \\
\text { /gud/ } \\
\text { /inglis/ }\end{array}$ & $\begin{array}{l}\text { /gad/ } \\
\text { /gud/ } \\
\text { /inglis/ }\end{array}$ \\
\hline
\end{tabular}

Based on the articulatory analysis, the students placed their tongue tip forward, lightly touching the back of the bottom front teeth. The jaw drops a little bit and the lips are open. Meanwhile, the lips position does not matter for these sounds because it might start forming the next sound. In contrast, based on the acoustic analysis that there were 5 out of 10 students did not articulate this voiced velar stop as it is presented acoustically in figure 8 . 


\section{G. The Vowel Mispronunciation}

The mispronunciations also were made by the students in pronouncing the English vowels inconsistently which categorized as the mistake. The following data were the sample of pronunciation variation.

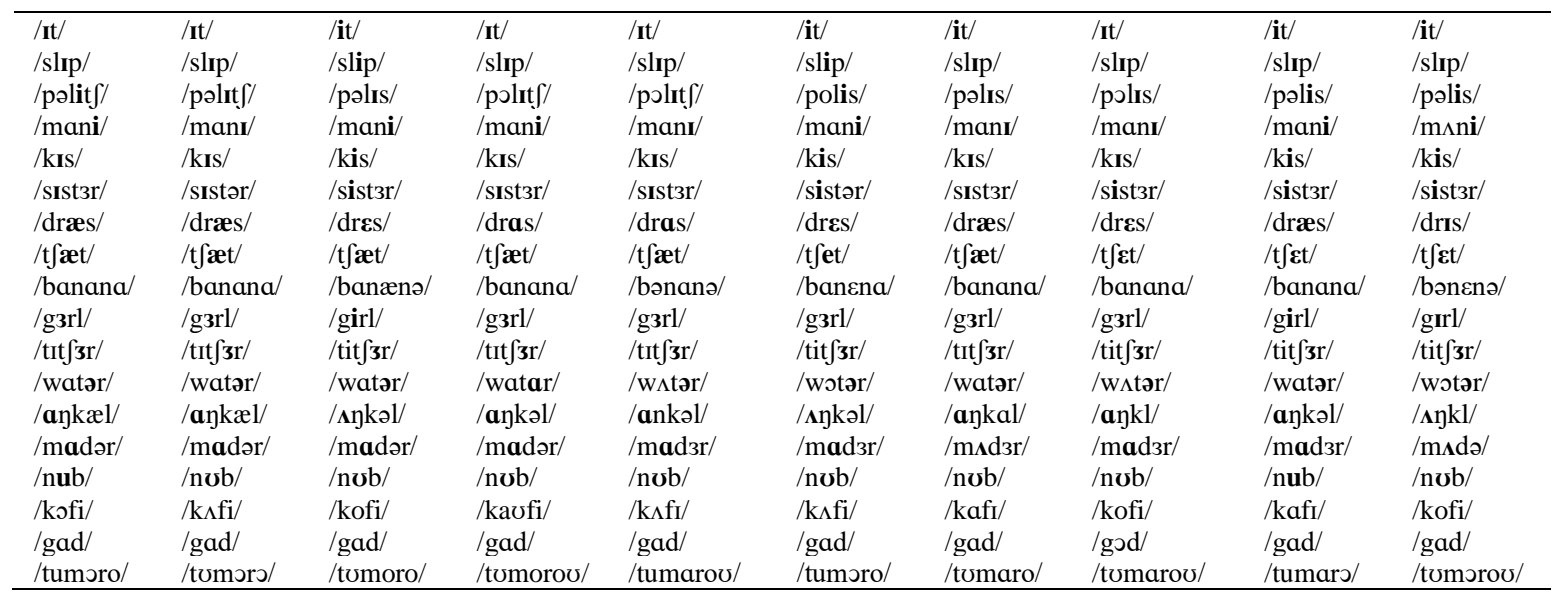

Based on data found related to English vowels mispronunciation presented above, the errors made by the first speaker as an example in pronouncing the [i] vowel that the speaker replaced [i] vowel to [I] vowel distributed in the initial and middle position of words eat and sleep. Meanwhile, this student articulated the [i] vowel without replacing it in another mid and final position in words police and money. Based on the acoustic data analysis, the formants frequency of F1 for viewing in the spectrum voiced bar that the vowel [i] as the sample distributed in word-middle position was in a bit higher frequency at $448 \mathrm{~Hz}$ to indicate [I] sound in the word sleep. Meanwhile, the frequency for F1 viewed a lower range at 263 to indicate a higher possible tongue position [i] vowel as the highest front vowel in the word police. This inconsistency or variations of students' pronunciation also appeared in the other vowels and also made by other students as it detailed presented in appendix 4 for the vowels pronunciation variation. Those other vowels were $[\varepsilon],[æ],[ə],[\Lambda],[3],[a],[u],[\mho]$, and [0] also inconsistently pronounced by the Lamaholot speakers as the second-graders Junior High Scholl in one of the schools located in East Adonara. To sum up, data found that the Lamaholot speakers were inconsistently mispronounced the English vowels that appeared based on their distributions in the word position. Therefore, the students mispronounced these English vowels indicated as a mistake rather than the error because those students did not replace the same vowel errors for its distribution in the same word position in the other words or inconsistently mispronounced a particular sound provided as the sample presented in appendix (figure $9 \& 10$ ).

\subsection{The Factor Caused Students' Pronunciation Errors}

In this part, the researcher presented another focused in conducting this study, which was to reveal the factors that caused the errors in pronouncing English segmental made by the Lamaholot Speakers. These factors were the inconsistency of the English sound system and the language transfer. 
A. The inconsistency of English sounds

The spelling is mostly consistent and fixed especially for the Lamaholot language, but English's is not. The learners mostly rely on the written representation of English sounds when they pronounced English words. Consequently, they mispronounced through the wrong analogy. There was no definite connection between sounds and letters in English (Hewings, 2004). It is noticeable that the word mission has (7) letters but only represents (4) sounds i.e. $/ \mathrm{mI} \mathrm{Jn} /$. This inconsistency also caused the speaker to mispronounce the English sounds. One of the inconsistencies of English sound systems found in the letter ' $s s$ ' in the words mission for [S] and dress for [s] was not the same to be pronounced caused the majority of students to mispronounced by pronouncing $/ \mathrm{mIs} ə \mathrm{n} /$ (the correct way is $/ \mathrm{mI} \mathrm{n} /$ ). Meanwhile, most students can pronounce this [J] sound distributed in the same word-middle position of word television. Furthermore, most students also mispronounced word noob by possibly following a false analogy from word early pronunciation. Both words 'noob' and 'book' carry the same letter 'oo' in their spelling. However, the letters are pronounced differently (pronounced $/ \mho /$ in 'book' but $/ \mathrm{u} /$ in 'noob'). Hence, it is arguable that this kind of mispronunciation categorized as mistakes since there were found some inconsistencies in English sounds pronounced by the students. Besides, those students were also found to replace both sounds when distributed in other words position.

\section{B. Interlingual Transfer}

Related to the errors made, Brown (2000) defines one of the causes of errors as an interlingual transfer. The Interlingual factor refers to the interference factor from the students' mother tongue or first language. This error occurs because of differences in the mother tongue system and the language system being studied. Based on the data found that the Lamaholot language is the first language or speakers' mother tongue, which is argued as another factor that caused the errors in pronouncing some English consonants. These consonants were the voiced Labiodental Fricative [v], voiceless [ $\theta]$ and voiced dental fricative [ð], voiceless [S] and voiced [3] post-alveolar affricative, and the voiced alveolar fricative [z]. As it was described in the previous chapter that those consonants did not exist in phonetic description of the Lamaholot language. Besides, the English short vowels [æ] and all English long vowels such as [i:], [a:], [o:], [u:], and [3:] are not recognized in the Lamaholot language did not caused the errors of students pronunciation.

In line with that, Nagaya (2010: 161-162) in research entitled A Phonological Sketch of Lewotobi Lamaholot revealed that Lamaholot language does not have these $\left[\mathrm{v}, \theta, \delta, \int, 3\right.$, and $\left.\mathrm{z}\right]$ based on the phonetic description of consonants. In the same vein, another previous research conducted by Hadroh (2020), the second-grade students in MTS Pasuruan also found it difficult to pronounced English consonants such as "ch"

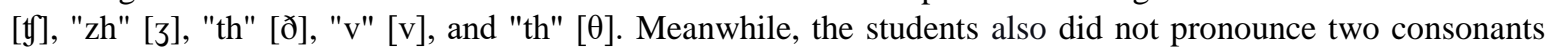
distributed in the word-final position. These two consonants were the voiceless bilabial stop [p] and the voiced alveolar stop [d]. In this special case of consonant clusters, there were some previous studies entitled $A$ Grammar of Solor-Lamaholot conducted by Kroon (2016) and Nagaya (2010) entitled A Phonological Sketch of Lewotobi Lamaholot revealed that there was a consonant cluster found in the word-initial position of its distribution for CCV syllabic structure found in the Lamalohot language of Solor dialect as well as in Lewotobi dialect. Meanwhile, the researcher as the native speaker of Lamaholot East Adonara dialect did not find any consonant clusters distributed in word position in Lamaholot Language in the East Adonara dialect.

\section{Conclusion}

This study investigated the English segmental pronunciation errors made by the Lamaholot speakers of second-graders Junior High School in East Adonara. Based on the phonetic data analyzed from the articulatory, auditory, and acoustic, the Lamaholot speakers mispronounced the English consonants and 
vowels. The consonants mispronunciation were such as $[\mathrm{p}],[\mathrm{d}],[\mathrm{g}],[\theta],[ð],[\mathrm{v}],[\mathrm{f}],[3]$ and $[\mathrm{z}]$. Moreover,

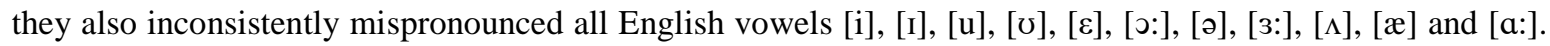
Based on the factors that caused the English segmental mispronunciation, the inconsistencies of English sounds can be argued as one of the factors that caused the speakers to inconsistently mispronounced the consonants [f], [g], and all the English vowel. The researcher found that this mispronunciation was inconsistently made by replacing them with each other. This category in the pronunciation inconsistency of English sounds above was indicated as a mistake and not as the error. Meanwhile, another factor that caused the errors in pronouncing the English sound was the interlingual transfer. It caused the consistent mispronunciation indicated as the errors because the speaker could not correct it when the related sounds appeared multiple times based on its word distribution. Those sounds were the cluster [p] and [d] distributed in the word-final position, $[\mathrm{v}]$ and $[\mathrm{z}]$ as the loan language voiced $[\mathrm{v}]$ which had always being replaced to $[\mathrm{f}]$ and voiced velar $[\mathrm{z}]$ always replaced to voiceless alveolar $[\mathrm{s}]$. Meanwhile the consonants $[\delta],[3][\theta],[ð]$ are also not appeared in Lamaholot phonetic description presented in the previous chapter. To sum up, this research conducted revealed that there were two factors caused the students mispronunciation, which were the inconsistency of English sound system and the interlingual transfer. Since this research focused on the pronunciation errors, there were some consonants pronunciation errors caused by the interlingual transfer. Those consonants errors made were the cluster [p] and [d], and other consonants $[\theta]$, [ð], [v], [J] [3] and [z].

\section{References}

Brown, H. D. 2000. Principles of Language Learning and Teaching ( $4^{\text {th }}$ ed). San Francisco: Longman.

Chaer, A. 2009. Fonologi Bahasa Indonesia. Jakarta: Rineka Cipta.

Crystal, D. 2008. A Dictionary of Linguistics and Phonetics. (6 $6^{\text {th }}$ ed). Blackwell Publishing.

Ellis, Rod. 1997. Second Language Acquisition. Oxford University Press.

Hewings, M. 2004. Pronunciation Practice Activities: A Resource Book for Teaching English Pronunciation. Cambridge University Press.

Kroon, Y. B. 2016. A Grammar of Solor-Lamaholot A Language of Flores, Eastern Indonesia. A Thesis for Doctor of Philosophy, Endangered of Language Studies, Department of Linguistics School of Humanities. The University of Adelaide, Australia.

Ladefoged, P. 2001. Vowels and Consonants. CD ROOM.

Ladefoged, P., \& Johnson, K. 2014. A Course in Phonetics ( $7^{\text {thed}}$ ). United States of America: CENGAGE Learning.

Lanteigne, B. 2006. Common, persistent errors in English by Brazilian Portuguese Speakers. TEFL Web Journal, 4(1). Retrieved August 21, 2006, from http://www.teflweb-j.org/v4n1/Brazilians.pd.

Muslich, Masnur. 2008. Fonologi Bahasa Indonesia: Tinjauan Deskriptif Sistem Bunyi Bahasa Indonesia. Jakarta: Bumi Aksara

Nagaya, N. 2010. A Ponological Sketch of Lewotobi Lamaholot. Asian and African Languages and Linguistics, Rice University. No.5

Odden, D. 2006. Introducing Phonology. Cambridge University Press.

Ogden, R. 2009. An Introduction to English Phonetics. Edinburgh University Press.

Pastika, I Wayan. 2019. Fonetik dan Fonologi: Tata Bunyi Bahasa. Pustaka Larasan.

Vernick, J., \& Nesgoda, J. 1980. American English Sounds and Spellings for Beginning ESL Students. Pittsburgh: University of Pittsburgh Press.

Yarmohammadi, L. 1996. A Contrastive Phonological Analysis of English and Persian. Shiraz: Shiraz University Press. 


\section{Appendix}

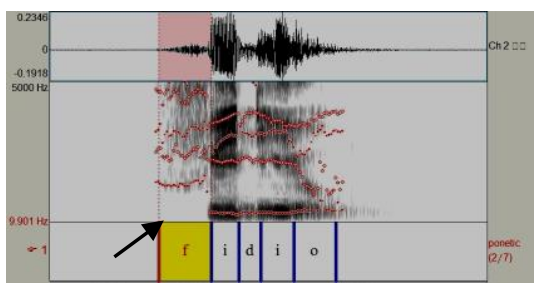

Figure 1. Replaced /v/ to /f/ video

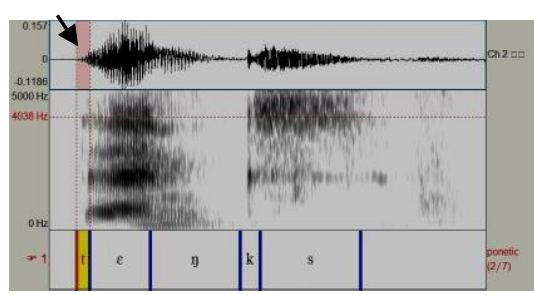

Figure 3. Replaced / $/ \theta /$ to $/ \mathrm{t} /$ in word thanks

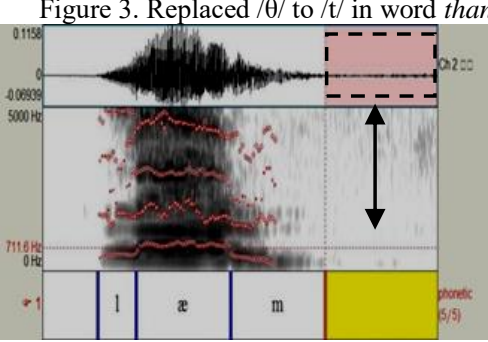

Figure 6. Did not pronounced /p/ lamp

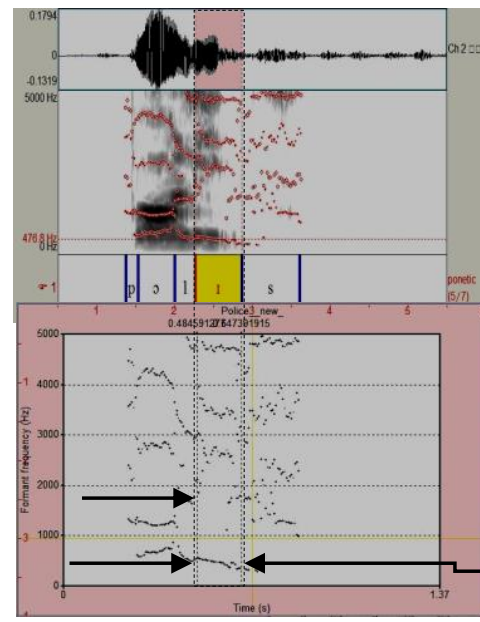

Figure 9. Replaced /i/ to /I/ in Police

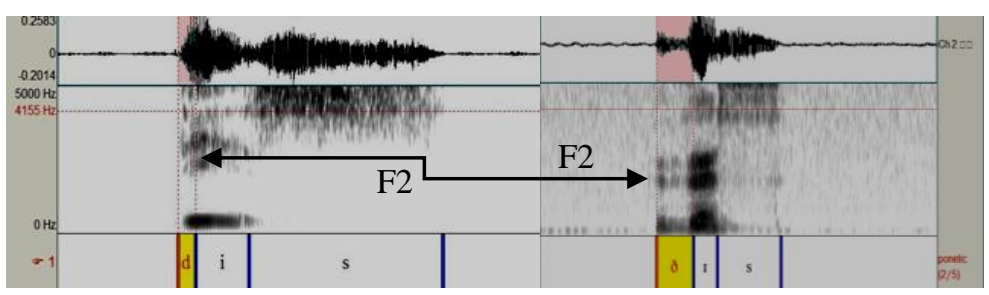

Figure 2. Replaced/ठ/ to /d/ in the word this
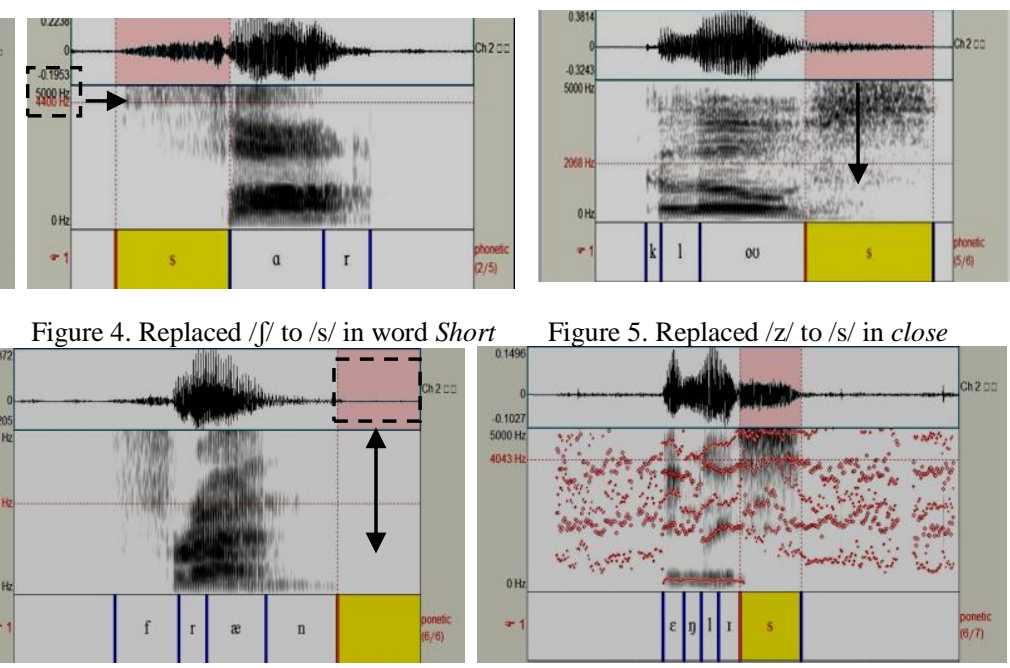

Figure 7. Did not pronounced /d/ friend

Figure 8. Did not pronounced /g/ english
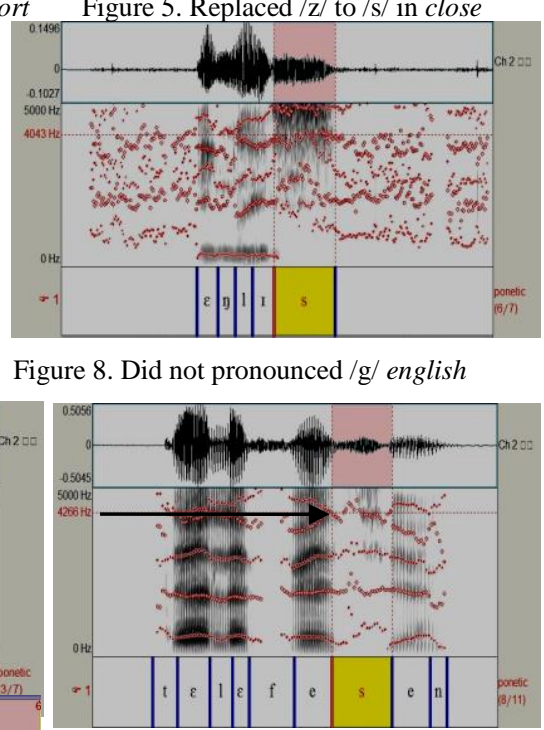

Figure 11. Replaced /z/ to /s/ in television

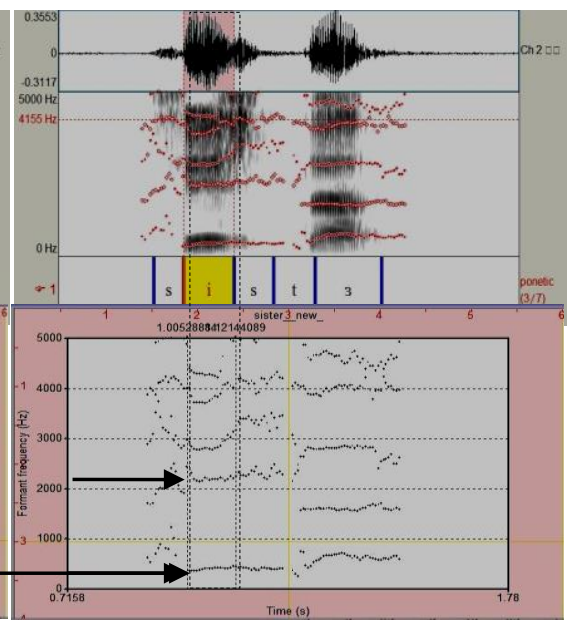

Figure 10. Replaced /I/ to /i/ in word sister 


\section{ACKNOWLEDGEMENT}

First of all, let the author give thanks before Almighty God because only by His grace, this thesis can be completed. On this occasion, please allow the author to express his deepest gratitude to Prof. Dr. I Wayan Pastika, M.S. as the first supervisor who has attentively provided encouragement, enthusiasm, guidance, and advice for the author during the master program, especially in completing this thesis. Thank you profusely to the author also to Dr. Anak Agung Putu Putra, M.Hum, the second supervisor who with full attention and patience has provided guidance and advice to the author.

The same remarks were also addressed to the Chancellor of Udayana University Prof. Dr. dr. A.A Raka Sudewi, Sp.S (K) for the opportunities and facilities given to the author to attend and complete the Linguistics Master Program education at Udayana University. This gratitude is also addressed to the Dean of the Faculty of Cultural Sciences, Udayana University who is held by Dr. Made Sri Satyawati, S.S. M.Hum for the opportunity given to the author to become a student of the Master Program in the Linguistics Study Program at the Faculty of Humanities, Udayana University.

On this occasion, the author also expressed his gratitude to the Head of the Study Program Prof. Dr. Drs. I Nyoman Suparwa, M.Hum, who guided in completing this research. the author also expresses his sincere gratitude and appreciation to all the teachers who have guided me, from elementary school to college. The author also thanks to the mother and father who have nurtured and raised the author, providing the basics of logical thinking and a democratic atmosphere to create a good ground for creativity development. Finally, the author would like to express his gratitude to the brothers who have given full of sacrifice the opportunity to the author to concentrate more on completing this thesis.

finally, may God Almighty always bestow His mercy on all those who have helped carry out the completion of this thesis as well as to the author and his family. 